Activity of porcine muscle glycogen debranching enzyme in relation to $\mathrm{pH}$ and temperature

Kylä-Puhju, Maria

Elsevier

2005

Meat Science. 2005. 69(1): 143-149.

http://hdl.handle.net/1975/688

http://dx.doi.org/10.1016/j.meatsci.2004.06.016

Downloaded from Helda, University of Helsinki institutional repository.

This is an electronic reprint of the original article.

This reprint may differ from the original in pagination and typographic detail.

Please cite the original version. 


\section{Activity of Porcine Muscle Glycogen Debranching Enzyme in Relation to $\mathrm{pH}$ and Temperature}

Maria Kylä-Puhju*, Marita Ruusunen, Eero Puolanne

Department of Food Technology, University of Helsinki, PO Box 27, Helsinki, Finland

Correspondence to: Maria Kylä-Puhju

University of Helsinki

Department of Food Technology

PO Box 66 (Viikki EE)

FIN-00014 University of Helsinki

FINLAND

Tel:

+358919157948

Fax:

$+358919158460$

E-mail address: $\quad$ maria.kyla-puhju@helsinki.fi

\footnotetext{
${ }^{1}$ Abbreviations GP: glycolytic potential - LD: longissimus dorsi muscle - ldGDE: longissimus dorsi muscle glycogen debranching enzyme - M: masseter muscle - mGDE: masseter muscle glycogen debranching enzyme

* Corresponding author
} 


\section{Abstract}

The activity of glycogen debranching enzyme (GDE) was studied in relation to $\mathrm{pH}$ value and temperature in porcine masseter and longissimus dorsi muscles. A glycogen limit dextrin was used as the substrate for GDE, and the enzyme was derived from raw meat extracts. In both muscles, the $\mathrm{pH}$ only weakly affected on activity of GDE at the $\mathrm{pH}$ values found in carcasses post-slaughter. However, the activity of GDE decreased strongly $(\mathrm{P}<0.001)$ when the temperature decreased from values of $39{ }^{\circ} \mathrm{C}$ and $42{ }^{\circ} \mathrm{C}$ found just after slaughter to values of $4{ }^{\circ} \mathrm{C}$ and $15^{\circ} \mathrm{C}$ found during cooling. In both muscles the activity of GDE began to fall at temperatures below $39{ }^{\circ} \mathrm{C}$ and was almost zero when the temperature decreased to below $15^{\circ} \mathrm{C}$. Thus, the activity of GDE may control the rate of glycogenolysis and glycolysis, but does not block rapid glycolysis and $\mathrm{pH}$ decrease when the temperature is high. This may be important in PSE meat, where the $\mathrm{pH}$ decreases rapidly at high temperatures, but rapid cooling could limit the activity of GDE and thus glycogenolysis. As expected, GDE was more active in the light longissimus dorsi muscle than in the dark masseter muscle.

Keywords: Pig; Muscle; Glycogen debranching enzyme activity; Temperature; pH

\section{Introduction}

In living muscle glycogen provides local fuel storage for short-term energy consumption. After slaughter glycogen degradation to lactate causes post-mortem $\mathrm{pH}$ decline in muscles. The rate and extent of $\mathrm{pH}$ decrease affects several meat quality traits. The complete degradation of glycogen is 
achieved by cooperation of two enzymes: glycogen phosphorylase (phosphorylase) and glycogen debranching enzyme (GDE) (Brown \& Brown, 1966). Mammalian GDE is a monomeric protein containing two independent catalytic activities: a glycan transferase (EC2.4.1.25) (transferase), and amylo-1,6-glucosidase (EC3.2.1.33) (glucosidase). The two activities occur at separate sites on a single polypeptide chain (Gordon, Brown \& Brown, 1972; White \& Nelson, 1974; Bates, Heaton, Taylor, Kernohan \& Cohen, 1975; Taylor, Cox, Kernohan \& Cohen, 1975).

Phosphorylase catalyses the sequential phosphorolysis of the outer chains of the glycogen molecule until it reaches the fourth glucose unit from the branch point of the molecule (Walker \& Whelan, 1960). Glycogen with four glucose units in every branch is called the limit dextrin state. The outer layer of limit dextrin has symmetric structure and it is converted back to an asymmetric structure by the transferase activity of GDE. This occurs by transferring a maltotriosyl group from the side chain to the main chain. The glucosidase hydrolyses the remaining glucosyl branch, producing free glucose. The debranched dextrin formed has long outer chains which are again susceptible to further degradation by phosphorylase (Brown \& Brown, 1966; Nelson, Kolb \& Larner, 1969; Nelson \& Larner, 1970).

Lawrie (1955) and recently Immonen (2000) showed that post-mortem glycogenolysis may stop even if there is glycogen left in the muscle and speculated that GDE may play a role in this process. Yurovitzky \& Milman (1975) suggested that the rate of glycogenolysis is limited by the activity of GDE. If the $\mathrm{pH}$ or temperature markedly affects the activity of GDE, it may influence the rate of post-mortem glycogenolysis and glycolysis and thus the ultimate $\mathrm{pH}$ of meat.

The aim of the present study was to investigate the activity of GDE in relation to $\mathrm{pH}$ value and temperature in porcine muscles. In addition, the $\mathrm{pH}$-activity and temperature-activity profiles of 
GDE and the glycolytic potential in light longissimus dorsi (LD) muscle and dark masseter (M) muscle were compared. The study focused on the combined activity of GDE only, not on the individual activities of the enzyme.

\section{Materials and Methods}

\subsection{Animals and sampling}

Muscle samples (LD and M) from 12 pigs were obtained from a commercial abattoir. The LD sample was obtained from the last rib about 35 min after stunning. The samples were diced, frozen and stored in liquid nitrogen. Freezing occurred within 1 min after sampling and the analyses were performed within two days after sampling.

The $\mathrm{pH}$-activity profiles of GDE for LD and $\mathrm{M}$ were determined in eight animals and temperatureactivity profiles in the muscles of four animals. Originally, the activity of GDE was determined at 5 , $15,25,35,39$ and $42{ }^{\circ} \mathrm{C}$ for the temperature-activity profiles and was further determined at higher temperatures $\left(39,42,50\right.$ and $\left.60{ }^{\circ} \mathrm{C}\right)$ in a few additional animals. Some of the same animals were used in determining $\mathrm{pH}$-activity profiles and activity at high temperatures.

\subsection{Activity of the GDE}

The activity of GDE was determined using the method of Nelson, Palmer \& Larner (1970) with small modifications. The method follows the change in the iodine-complex spectrum of glycogen phosphorylase limit dextrin (limit dextrin), a natural substrate for GDE. In the present study the

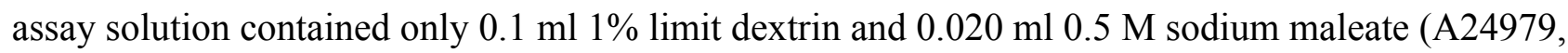
Sigma-Aldrich). Reaction was started by adding $0.08 \mathrm{ml}$ meat extract. The meat extract was 
prepared daily, using $2.5 \mathrm{ml}$ buffer which contained $0.05 \% \mathrm{KHCO}_{3}$ and $0.004 \mathrm{M}$ EDTA (pH approx. 7.8 at $25^{\circ} \mathrm{C}$ ) per $1 \mathrm{~g}$ wet weight muscle. The mixture was homogenised (Ultra-Turrax T25, Janke \& Kunkel, Germany) and centrifuged (Sorvall Instruments RC5C) $10 \mathrm{~min}, 10^{\circ} \mathrm{C}$ and $30000 \mathrm{G}$. The supernatant was used in the measurements.

The reaction was stopped in a boiling-water bath followed by immersion in an ice bath. The reaction times were 1, 1.5 and $2.5 \mathrm{~min}$ for $\mathrm{LD}$ muscle and 1, 2.5 and 4.0 min for M muscle. Iodine reagent $(2.6 \mathrm{ml})$ was added to a stopped reaction mixture and the absorbance $(525 \mathrm{~nm})$ recorded after $20 \mathrm{~min}$. The iodine reagent was prepared according to Nelson et al. (1970) by dissolving $0.26 \mathrm{~g}$ of $\mathrm{I}_{2}$ and $2.6 \mathrm{~g} \mathrm{KI}$ in $10 \mathrm{ml}$ water. The $\mathrm{I}_{2}-\mathrm{KI}$ solution $(1.0 \mathrm{ml})$ was added to $260 \mathrm{ml}$ of saturated $\mathrm{CaCl}_{2}$ solution ( $\mathrm{pH}$ at 1 to 10 dilution $5.6-6.2$ ) to produce the iodine reagent. Method blanks (zero time controls) were prepared by denaturing the meat extract protein in the boilingwater bath before adding the other reagents.

For determining the $\mathrm{pH}$-activity profiles of the GDE, the $\mathrm{pH}$ values of the sodium maleate were $\mathrm{pH}$ 9.0, $6.5,6.1,6.0,5.9,5.6$ or 5.1 (adjusted with $\mathrm{HCl}$ ) and the corresponding $\mathrm{pH}$ of the reaction mixtures was about $7.2,6.8,6.4,6.3,6.2,6.0$ or 5.6 . The maleate buffers were always heated in a water bath $\left(90^{\circ} \mathrm{C}\right)$ before adding to the assay solution. In this study, the assay solution was incubated at $39{ }^{\circ} \mathrm{C}$ to balance out the temperature and the reaction was started by adding the meat extract. The temperature-activity profiles of the GDE were determined similarly, but the $\mathrm{pH}$ of the reaction mixture was adjusted to $6.3 \pm 0.05$ and the reaction mixture was incubated at $4,15,25,35$, $39,42,50$ or $60{ }^{\circ} \mathrm{C}$ before adding the meat extract. The temperature $\left(39{ }^{\circ} \mathrm{C}\right)$ for determining the $\mathrm{pH}$ activity profiles and the $\mathrm{pH}$ (6.3) for determining the temperature-activity profiles of GDE and the reaction times used for different muscles were defined in preliminary experiments. 
The absorption spectra between $375 \mathrm{~nm}$ and $800 \mathrm{~nm}$ of the method blank and the reaction mixtures were also obtained after a 5-fold dilution of the polysaccharide-iodine solution with additional iodine reagent. All the absorbance and absorption spectra measurements were obtained with a Lambda 2 spectrometer (Perkin Elmer).

\subsection{Preparation of limit dextrin}

Limit dextrin is not available commercially. It was synthesised in our laboratory according to the method of Werries, Franz \& Geisemeyer (1990). Commercially available rabbit muscle phosphorylase a (P1261, Sigma-Aldrich, St. Louis, MO, USA) was first separated from traces of GDE by passing it through a column $(1.6 \times 12 \mathrm{~cm})$ of $\omega$-aminobutyl agarose (A6142, SigmaAldrich) that was equilibrated at $4{ }^{\circ} \mathrm{C}$ with $5 \mathrm{mM}$ Tris buffer $(\mathrm{pH}$ 7.2)/1 mM EDTA/14 mM 2mercaptoethanol (Chen, He, Ding \& Brown, 1987). Unadsorbed protein was washed off until the absorbance at $280 \mathrm{~nm}$ decreased to below 0.05 (Biorad Econo UV monitor EM-1, USA). The elution rate was $1 \mathrm{ml} / \mathrm{min}$. After the first elution the column was washed with the same solvent containing $250 \mathrm{mM} \mathrm{NaCl}$ and the eluant which contained phosphorylase was collected.

The eluant was dialysed against water and lyophilised (Heto DW8-85, Hetoholten, Denmark). The activity of phosphorylase was measured spectrophotometrically (absorbance $340 \mathrm{~nm}$, Perkin Elmer Lambda 2 spectrometer, Überlingen, Germany) according to Bass, Brdiczka, Eyer, Hofer \& Pette (1969) following the release of glucose-1-phosphate from glycogen with L-cysteine, NaDP (N8129, Sigma-Aldrich), glucose-1,6-diphosphate, AMP, phosphoglucomutase (rabbit muscle, 79440, Fluga Chemie GmbH, Buchs, Switzerland) and glucose-6-phosphate-dehydrogenase (127671, Roche, Indianapolis, USA). 
Purified, GDE-free, phosphorylase $a$ was added to $350 \mathrm{mg}$ glycogen (bovine liver, G0885, SigmaAldrich) in $5 \mathrm{ml} 0.05 \mathrm{M}$ phosphate buffer (pH 6.8). In the present study the solution also contained $0.1 \mathrm{mM}$ 5'AMP (01930, Fluga). The solution was dialysed at $37{ }^{\circ} \mathrm{C}$ against $150 \mathrm{ml}$ of the same buffer. The buffer was changed every $12 \mathrm{~h}$ and the released glucose-1-phosphate was analysed enzymatically. The digest was mixed with trichloroacetic acid (final concentration $10 \% \mathrm{v} / \mathrm{v}$ ), dialysed against water and centrifuged for $10 \mathrm{~min}$ at $1000 \mathrm{~g}$. The limit dextrin formed was precipitated with four volumes of ethanol, centrifuged (5 min, $1000 \mathrm{~g})$, washed twice with ethanol and dried.

\subsection{Lactate and glycogen concentrations and the activity of phosphorylase}

For lactate and glycogen determinations, muscle samples were homogenised in ice-cold $0.1 \mathrm{M}$ phosphate buffer ( $\mathrm{pH} 7.0)$ with a Polytron homogeniser. The lactate concentration was determined spectrophotometrically (365 nm) using a commercial kit (Boeringer-Mannheim no. 139 084).

Glycogen concentration was determined by hydrolysing the homogenate in $0.1 \mathrm{M} \mathrm{HCl}$ at $100{ }^{\circ} \mathrm{C}$ for $2 \mathrm{~h}$, after which the $\mathrm{pH}$ was adjusted to 6.5-7.5 (Lowry \& Passoneau, 1973) and glucose determined with a Roche diagnostic kit no. 1447521.

The glycolytic potential (GP) was calculated according to Monin \& Sellier (1985): GP = $2([$ glycogen $]+[$ glucose $]+[$ glucose-6-phosphate $])+[$ lactate $]$. In the present study the concentrations of glucose and glucose-6-phosphate were determined simultaneously.

The activity of phosphorylase in the muscle samples was assayed as described above in connection with the preparation of phosphorylase limit dextrin. 
The reproducibility of the assays was determined as follows: a large muscle sample was ground up in liquid nitrogen, diced and stored at $-80^{\circ} \mathrm{C}$. This sample was analysed every time the samples were analysed. The coefficients of variation (CVs) were $\pm 8.7 \%, \pm 10.8 \%$ and $\pm 11.3 \%$ for the lactate and glycogen concentrations and activity of phosphorylase, respectively.

\subsection{Statistical analysis}

Statistical analysis was performed with the Statistical Analysis System version 8.02 (SAS, 1990). The REG procedure was applied when calculating the parameter estimates in the regression equation. The mixed procedure with Bonferroni adjustment was applied when calculating the least squares means of the variables in the temperature-activity profiles of GDE. The curves were fitted using SAS/insight and the curves were plotted with Microsoft Excell 97 SR-2 (XY(scatter), polynomial trendline). The $\mathrm{pH}$ and temperature values for maximum enzymatic activity were read from the curves whenever possible.

\section{Results}

\section{1. pH-activity profiles for porcine longissimus dorsi and masseter muscles GDE}

Porcine longissimus dorsi muscle GDE (ldGDE) breaks down its natural substrate, limit dextrin, very rapidly. The porcine masseter muscle GDE (mGDE) degraded limit dextrin considerably more slowly than the ldGDE; the rate of change of the absorbance per minute was slower and the overall absorbance remained low. Based on these measurements, both the ldGDE and the mGDE were active at $\mathrm{pH}$ values normally found in muscles post-mortem (Figs. 1(a) and (b)). The maximum activity of ldGDE was around $\mathrm{pH}$ 6.5. In the $\mathrm{pH}$ range studied the activity of mGDE increases slightly when the pH decreases (Fig. 1(b)). 
The absorption spectra for the zero sample and for the reaction at different stages (reaction times for LD 1.0, 1.5 and $2.5 \mathrm{~min}$ and for M 1.0, 2.5 and $4.0 \mathrm{~min}$ ) were scanned to ensure the progress of the reaction (data not shown). The activity of GDE causes the absorption spectra of limit dextrin to approach to that of glycogen more closely (Nelson et al., 1970). However, the spectra were not that close to the absorption spectra of glycogen, which indicates that substrate availability was not a limiting factor, i.e. the reaction had the potential to continue at maximum velocity.

\subsection{Temperature-activity profiles for porcine longissimus dorsi and masseter muscles GDE} In both muscles, the activity of GDE was higher $(\mathrm{P}<0.001)$ at those temperatures found in the carcass just after slaughter $\left(39^{\circ} \mathrm{C}\right.$ and $\left.42{ }^{\circ} \mathrm{C}\right)$ than at temperatures found during cooling $\left(4{ }^{\circ} \mathrm{C}\right.$ and $\left.15^{\circ} \mathrm{C}\right)$. In M muscle a significant $(\mathrm{P}<0.01)$ difference was also shown in activity of GDE between temperatures of $39^{\circ} \mathrm{C}$ and $25^{\circ} \mathrm{C}$.

The optimum temperature for ldGDE was $39^{\circ} \mathrm{C}$ (Fig. 2(a)) and for mGDE near $50^{\circ} \mathrm{C}$ (Fig. 2(b)). Activity of GDE in both muscles began to fall at temperatures below $39{ }^{\circ} \mathrm{C}$ and was almost zero when the temperature was to below $15^{\circ} \mathrm{C}$. As with the $\mathrm{pH}$-activity profiles, the temperature-activity profiles also indicate that GDE was more active in light LD muscle than in dark M muscle.

\subsection{Glycolytic capacity of the muscles}

The glycogen and lactate concentrations, GP and activity of phosphorylase of the muscles studied are shown in Table 1. As expected, the activity of phosphorylase, lactate concentration and GP were higher and the $\mathrm{pH}$ value measured 35 min post-slaughter was lower in LD muscle than in M muscle. The activity of phosphorylase in LD muscle was almost 7-fold and GP 55.7 units higher than in M muscle. 


\section{Discussion}

The $\mathrm{pH}$-activity profiles were determined with maleate buffer for porcine ldGDE and mGDE over the $\mathrm{pH}$ range (from 5.0 to 7.4 ) found in muscles post-mortem. Various buffers affect the $\mathrm{pH}$ optimum of GDE (Gordon et al., 1972). In the present study, the $\mathrm{pH}$ only weakly affected the activity of porcine GDE. In long-lasting moderate exercise, the $\mathrm{pH}$ of a living muscle does not decrease, but intensive exercise may result in a sharp $\mathrm{pH}$ decrease, from above 7 at rest to a value as low as 6.0 during exercise (Taylor, Bore, Styles, Gadian \& Radda, 1983). Hence, GDE must have the capability for being active over a large range of $\mathrm{pH}$ values to ensure continuous glycogenolysis and glycolysis and thus carry on energy production. Becker, Long \& Fischer (1977) have found that the $\mathrm{pH}$ optimum for dogfish GDE was in between 5.5 and 6.3, which is close to the $\mathrm{pH}$ range used in the present study.

However, the $\mathrm{pH}$-activity profiles of ldGDE and mGDE were different. The maximum activity of ldGDE was about $\mathrm{pH} 6.5$, but a relative maximum $\mathrm{pH}$ value for mGDE was not found in the $\mathrm{pH}$ range studied. Taylor \& Whelan (1968) reported that there may be two GDE isoforms in the rabbit muscle or one enzyme with a double $\mathrm{pH}$ optimum. They speculated that if there are two GDEs, one may have a preference for high-molecular-weight substrates. The wide $\mathrm{pH}$ range of the activity within muscle and the different $\mathrm{pH}$-activity profiles for mGDE and ldGDE found in here may also suggest that there could be different GDE isoforms or activation mechanisms in these muscles. There is only one GDE gene in the human genome (Bao, Dawson \& Chen, 1996), but recently Bao, Yang, Dawson \& Chen (1997) found six GDE mRNA isoforms in human muscle. It is not yet known whether all of these isoforms can produce a functional GDE protein. 
GDE was slightly more active at lower than higher $\mathrm{pH}$ values in the dark $\mathrm{M}$ muscle, possibly because in the living animal the lactate formed in type IIB muscle fibres is transported out of the fibres, either to the bloodstream or to type I muscle fibres (Halestrap \& Price, 1999), resulting in a $\mathrm{pH}$ decrease in these fibres. Type I muscle fibres can produce energy from lactate by oxidation, thus the predominantly oxidative dark muscles (Briskey, 1964) do not need to use glycogen as an energy source when the $\mathrm{pH}$ is high, i.e. the activity of GDE is not critical. However, dark muscles must have the capability to break down glycogen at low $\mathrm{pH}$ values $(\mathrm{pH}<6)$ if their oxygen stores are depleted (the low pH maximum for activity of GDE). During continuous exercise, situations may arise in which the type IIB fibres become exhausted, but the type I fibres must continue to function. Energy can in such situations still be produced anaerobically from glycogen, and thus the activity of glycogenolytic enzymes at low $\mathrm{pH}$-values is critical.

In LD muscle the optimum temperature for activity of GDE was $39^{\circ} \mathrm{C}$. The activity began to rapidly to fall when the temperature decreased to below $35^{\circ} \mathrm{C}$, and the enzyme was practically inactive at temperatures below $15^{\circ} \mathrm{C}$. The other glycogen degrading enzyme, phosphorylase, is also most active at normal body temperatures (Cori, Cori \& Green, 1943).

For mGDE the optimum temperature was near $50{ }^{\circ} \mathrm{C}$. The decrease in activity of mGDE began immediately after the temperature had decreased to below body temperature $\left(38.5 \pm 0.65^{\circ} \mathrm{C}\right.$; Hannon, Bossone \& Wade, 1990), but the decrease in activity of ldGDE did not begin until the temperature had decreased to below $35^{\circ} \mathrm{C}$. Nelson \& Watts (1974) showed that the temperature optimum for rabbit muscle GDE combined activity was near $50{ }^{\circ} \mathrm{C}$ and that the activity sharply decreases when the temperature decreases to $20^{\circ} \mathrm{C}$ which is consistent with the results of the present study. 
We assume that the decrease in the activity of GDE caused by the temperature decrease also takes place in carcasses after slaughter. During the normal chilling procedure used in Finland, the core temperature of porcine LD muscle decreases to below $35^{\circ} \mathrm{C}$ in about $1 \mathrm{~h}$ post-mortem. At that time the $\mathrm{pH}$ has decreased to about 6.3 and the glycogen (assumed concentration at the time of slaughter has been normal or high) is still in a state which is susceptible to degradation by phosphorylase. The temperature decrease of the muscles due to cooling of the carcass decreases the activity of GDE and limits glycogenolysis and glycolysis. Thus, the decrease in the activity of GDE may delay the rate of glycogenolysis and glycolysis post-mortem.

In dark M muscle the decrease in the activity of GDE and in the rate of glycogenolysis was faster than in the light LD muscle. This is supported by the findings that M muscle temperature decreases faster and that even a slight decrease in temperature significantly reduces the activity of GDE. Mélendez-Hevia et al. (1993) have estimated that at most $34.6 \%$ of glycogen molecule is directly susceptible to the degradation by phosphorylase. We estimated that this amount is enough to cause the $\mathrm{pH}$ to decrease from 7.0 to about 6 in dark porcine $\mathrm{M}$ muscle post-mortem. After that the activity of GDE is needed so that glycogenolysis can continue. However, the final pH in dark porcine muscles usually remains close to six: infraspinam 5.89 \pm 0.16 (Kylä-Puhju, Ruusunen,

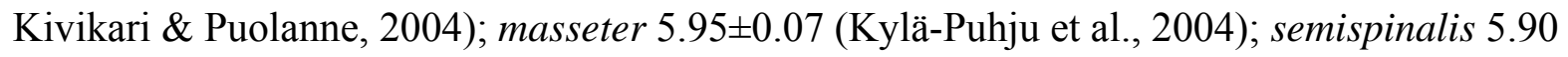
(Lefaucheur et al., 1991), 6.23 \pm 0.33 (Przybylski, Vernin, \& Monin, 1994) and vastus intermedius 6.23 (Bendall, 1979). Thus, the high final $\mathrm{pH}$ in $\mathrm{M}$ muscle may be due to a rapid temperature decrease in the muscle during cooling which decreases the activity of mGDE and leads to delayed glycogenolysis. 
Beecher, Briskey \& Hoekstra (1965) showed that post-mortem glycolysis is more rapid at $37^{\circ} \mathrm{C}$ than at $4{ }^{\circ} \mathrm{C}$ in both light and dark portions of porcine semitendinosus muscle. Their results showed that the glycolytic and glycogenolytic enzymes had some activity also at low temperatures. The present study showed that the activity of GDE became very slow when the temperature decreased to below $15{ }^{\circ} \mathrm{C}$. Beecher et al. (1965) found no significant differences between the final $\mathrm{pH}$ values of the light portions of semitendinosus muscle held at $37^{\circ} \mathrm{C}$ or at $4{ }^{\circ} \mathrm{C}$, but the final $\mathrm{pH}$ of the dark part of the semitendinosus muscle was significantly lower in muscles held at $37{ }^{\circ} \mathrm{C}$ than at $4{ }^{\circ} \mathrm{C}$. This is also consistent with our results that show that the light LD muscle GDE had activity under $25{ }^{\circ} \mathrm{C}$, in contrast to the dark $\mathrm{M}$ muscle enzyme. Thus, the decrease in activity of GDE due to temperature decrease probably stops the glycolysis earlier in the dark M muscle than in the light LD muscle.

The GP is an estimate of the glycogen content present at the moment of slaughter (Monin \& Sellier, 1985) as calculated from the GP, after 35 min post-mortem, the glycogen concentration decreased $25.8 \mathrm{mmol} / \mathrm{kg}$ in LD muscle and only $10.5 \mathrm{mmol} / \mathrm{kg}$ in M muscle. The corresponding lactate accumulation was $51.6 \pm 11.1$ and $21.0 \pm 4.1 \mathrm{mmol} / \mathrm{kg}$, respectively, but the $\mathrm{pH}$ value was only 0.11 units lower in LD than in M muscle. This is probably the result of the higher buffering capacity in LD compared with M muscle (Kylä-Puhju et al., 2004). The rate of glycolysis was thus 2.5-fold higher in LD than in M muscle. The activity of phosphorylase was almost 7-fold higher and the activity of GDE at $42{ }^{\circ} \mathrm{C} 2.4-$ fold higher in LD than in M muscle.

The glycogen limit dextrin is the specific substrate for the debranching enzyme, and the other enzymes present in the muscles do not break it down (Nelson et al., 1970). In this study glycogen limit dextrin was used as a substrate for GDE, which was derived from raw meat extracts. Nelson et al. (1970) showed that an assay for tissue extracts utilizing a modification of the iodine-complex 
spectrum for glycogen limit dextrin is specific for combined glucosidase-transferase activity. Thus, the resulting $\mathrm{pH}$-activity and temperature-activity profiles for GDE were related to that part of the activity (glucosidase or transferase) that was the rate-limiting step in the debranching. Furthermore, raw meat extracts provide a natural environment for the enzymatic action. Consequently, the conditions are more similar to those actually in the cell than is the case with purified enzymes. However, probably not all glycogen occurs in limit dextrin form in living muscle. In the present study, we used glycogen limit dextrin because we focused on the role of GDE in glycogenolysis and glycolysis.

It can be concluded that GDE is more active in porcine LD muscle than in M muscle. Temperature had a greater influence than $\mathrm{pH}$ on activity of GDE in both muscles. GDE from both muscles is active in the $\mathrm{pH}$ range found in carcasses post-slaughter; however, the post-mortem muscle temperature decrease strongly reduces the activity of GDE and may also control glycolysis. Thus, the activity of GDE does not block rapid glycolysis and $\mathrm{pH}$ decrease when the temperature is high while the enzyme maintains its activity even at temperatures above $45^{\circ} \mathrm{C}$. This may be important in pale soft and exudative (PSE) meat, where the $\mathrm{pH}$ decreases rapidly at high temperatures, but rapid cooling could reduce GDE activity and thus glycolysis. The eventual impact of activity of GDE on PSE pork and cold shortening in beef warrants further study.

\section{Acknowledgements}

The authors thank the slaughterhouse Koiviston Teurastamo Oy for providing the muscle samples. The cooperation and technical assistance with sampling provided by Production Manager M.Sc. 
Merja Vahva and her skilled personnel were greatly appreciated. We thank Laboratory Technician

Irja Korhonen for biochemical analyses.

\section{References}

Bao, Y., Dawson, T. \& Chen, Y-T. (1996). Human glycogen debranching enzyme gene (AGL): complete structural organization and characterization of the 5' flanking region. Genomics, 38, 155-165.

Bao, Y., Yang, B.-Z., Dawson, T.L. \& Chen, Y.-T. (1997). Isolation and nucteotide sequence of human liver glycogen debranching enzyme mRNA: identification of multiple tissue-specific isoforms. Gene, 197, 389-398.

Bass, A., Brdiczka, D., Eyer, P., Hofer, S. \& Pette, D. (1969). Metabolic differentiation of distinct muscle types at the level of enzymatic organization. European Journal of Biochemistry, 10, 198206.

Bates, E.J., Heaton, G.M., Taylor, C., Kernohan, J.C. \& Cohen P. (1975). Debranching enzyme from rabbit skeletal muscle; evidence for the location of two active centres on a single polypeptide chain. FEBS Letters, 58(1), 181-185.

Becker, J.-U., Long, T.J. \& Fischer, E.H. (1977). Purification and properties of debranching enzyme from dogfish muscle. Biochemistry, 16(2), 291-297.

Beecher, G.R., Briskey, E.J.. \& Hoekstra, W.G. (1965). A comparison of glycolysis and associated changes in light and dark portions of the porcine semitendinosus. Journal of Food Science, 30, 477-486.

Bendall, J. R. (1979). Relations between muscle $\mathrm{pH}$ and important biochemical parameters during the post-mortem changes in mammalian muscles. Meat Science, 3, 143-157.

Briskey, E. J. (1964). Etiological status and associated studies of pale, soft, exudative porcine musculature. Advances in food research, 13, 89-178.

Brown, D. H. \& Brown, B. I. (1966). In S. P. Colowick \& N. O. Kaplan, Methods in Enzymology (Vol. 8) (pp. 515-524). New York: Academic Press.

Chen, Y.-T., He, J.-K., Ding, J.-H. \& Brown, B. I. (1987). Glycogen debranching enzyme: purification, antibody characterization, and immunoblot analyses of type III glycogen storage disease. American Journal of Human Genetics, 41, 1002-1015.

Cori, C. F., Cori, G. T. \& Green, A. A. 1943. Crystalline muscle phosphorylase. III. Kinetics. Journal of Biological Chemistry, 151, 39-55.

Gordon, R. B., Brown, D. H. \& Brown, B. I. (1972). Preparation and properties of the glycogendebranching enzyme from rabbit liver. Biochimica et Biophysica Acta, 289, 97-107.

Halestrap, A. P. \& Price, N. T. (1999). The proton-linked monocarboxylate transporter (MCT) family: structure, function and regulation. Biochemical Journal, 343, 281-299.

Hannon, J. P., Bossone, C. A. \& Wade, C. E. (1990). Norman physiological values for conscious pigs used in biomedical research. Laboratory Animal Science, 40(3), 293-298.

Immonen, K. (2000). Bovine muscle glycogen concentration in relation to diet, slaughter and ultimate beef quality. EKT-series 1203. Academic dissertation, University of Helsinki, Department of Food Technology. Helsinki: Helsinki University Press.

Kylä-Puhju, M., Ruusunen, M., Kivikari, R. \& Puolanne, E. (2004). The Buffering Capacity of Porcine Muscles. Meat Science, 67(4), 587-593.

Lawrie, R.A. (1955). Residual glycogen at high ultimate $\mathrm{pH}$ in horse muscle. Biochimica et Biophysica Acta, 17, 282-283. 
Lefaucheur, L., Le Dividich, J., Mourot, J., Monin, G., Ecolan, P. \& Krauss, D. (1991). Influence of environmental temperature on growth, muscle and adipose tissue metabolism, and meat quality in swine. Journal of Animal Science, 69, 2844-2854.

Lowry, O.H. \& Passoneau, J.V. (1973). A flexible system of enzymatic analysis. New York: Academic Press.

Meléndez, R., Meléndez-Hevia, E. \& Cascante, M. (1997). How did glycogen structure evolve to satisfy the requirement for rapid mobilization of glucose? A problem of physical constraints in structure building. Journal of Molecular Evolution, 45, 446-455.

Monin, G. \& Sellier, P. (1985). Pork of low technological quality with a normal rate of muscle $\mathrm{pH}$ fall in the immediate post-mortem period: The case of the Hampshire breed. Meat Science, 13, 49-63.

Nelson, T. E. \& Larner, J. (1970). Studies on the action of amylo-1,6-glucosidase. Biochimica et Biophysica Acta, 198, 538-545.

Nelson, T. E. \& Watts, T. E. (1974). The effect of denaturing conditions on the activity of rabbit muscle amylo-1,6-glukosidase/oligo-1,4 $\rightarrow$ 1,4-glucantransferase. Molecular \& Cellular Biochemistry, 5(3), 153-159.

Nelson, T. E., Kolb, E. \& Larner J. (1969). Purification and properties of rabbit muscle amylo-1,6glucosidase-oligo-1,4 $\rightarrow$ 1,4-transferase. Biochemistry, 8(4), 1419-1428.

Nelson, T. E., Palmer, D. H. \& Larner, J. (1970). An investigation of the properties of rabbit muscle oligo-1,4 $\rightarrow$ 1,4-glucantransferase. Biochimica et Biophysica Acta, 212, 269-280.

Przybylski, W., Vernin, P. \& Monin, G. (1994). Relationship between glycolytic potential and ultimate $\mathrm{pH}$ in bovine, porcine and ovine muscles. Journal of Muscle Foods, 5(3), 245-255.

SAS Institute Inc. (1990). SAS/STAT User's Guide. Version 6. Fourth edition, Vol. 2. Gary, NC, USA, $846 \mathrm{p}$.

Taylor, D. J., Bore, P. J., Styles, P., Gadian, D. G. \& Radda, G. K. 1983. Bioenergetics of intact human muscle a ${ }^{31} \mathrm{P}$ nuclear magnetic resonance study. Molecular Biology \& Medicine, 1, 77-94.

Taylor, C., Cox, A., Kernohan, J. \& Cohen, P. (1975). Debranching enzyme from rabbit skeletal muscle. European Journal of Biochemistry, 51, 105-115.

Taylor, P. M. \& Whelan, W. J. (1968). Rabbit muscle amylo-1,6-glucosidase; properties and evidence of heterogeneity. In W.J. Whelan (ed.), Control of Glycogen Metabolism (Vol. 13) (pp. 101-114). Oslo: Universitetsforlaget, and London: Academic Press.

Walker, G. J. \& Whelan, W. J. (1960). The mechanism of carbohydrase action 8. Structures of the muscle-phosphorylase limit dextrins of glycogen and amylopectin. Biochemical Journal, 76, 264-268.

Werries, E., Franz, A., Geisemeyer, S. (1990). Detection of glycogen-debranching system in trophozoites of Entamoeba histolytica. Journal of Protozoology, 37(6): 576-580.

White, R. C. \& Nelson, T. E. (1974). Re-evaluation of the subunit structure and molecular weight of rabbit muscle amylo-1,6-glucosidase/4- $\alpha$-glucanotransferase. Biochimica et Biophysica Acta, 365, 274-280.

Yurovitzky, Y. G. \& Milman, L. S. (1975). Amylo-1,6-glucosidase (debranching enzyme), a pacemaker of glycogenolysis in the early development of teleosteans. Ontogenez, 6(3), 291-295. In Russian. 
Fig. 1. Activity of glycogen debranching enzyme from porcine longissimus dorsi muscle (a) and porcine masseter muscle (b) at different $\mathrm{pH}$ values.

Fig. 2. Activity of GDE from porcine longissimus dorsi muscle (a) and porcine masseter muscle (b) as a function of temperature. 
Table 1. Activity of phosphorylase, glycogen and lactate concentrations, glycolytic potential and $\mathrm{pH}$ 35 min post-slaughter for longissimus dorsi and masseter muscles of pigs.

\begin{tabular}{lccc}
\hline & M. longissimus dorsi & M. masseter & Significance \\
\hline Phosphorylase, U/g muscle & $14.2 \pm 3.2$ & $2.1 \pm 0.7$ & $* * *$ \\
Glycogen conc., mmol/kg & $67.6 \pm 21.8$ & $55.1 \pm 12.5$ & $\mathrm{~ns}$ \\
Lactate conc., $\mathrm{mmol} / \mathrm{kg}$ & $51.6 \pm 11.1$ & $21.0 \pm 4.1$ & $* * *$ \\
Glycolytic potential, mmol lactate & $186.9 \pm 38.9$ & $131.2 \pm 27.6$ & $* * *$ \\
$\quad$ equivalent/kg muscle & $6.73 \pm 0.06$ & $6.84 \pm 0.08$ & $* * *$ \\
pH 35 min post-slaughter & & & \\
\hline
\end{tabular}

Values are mean $\pm \operatorname{STDEV}(\mathrm{n}=12)$

$* * * \mathrm{P}<0.001, \mathrm{~ns}$, no significant difference 
Fig. 1

a)

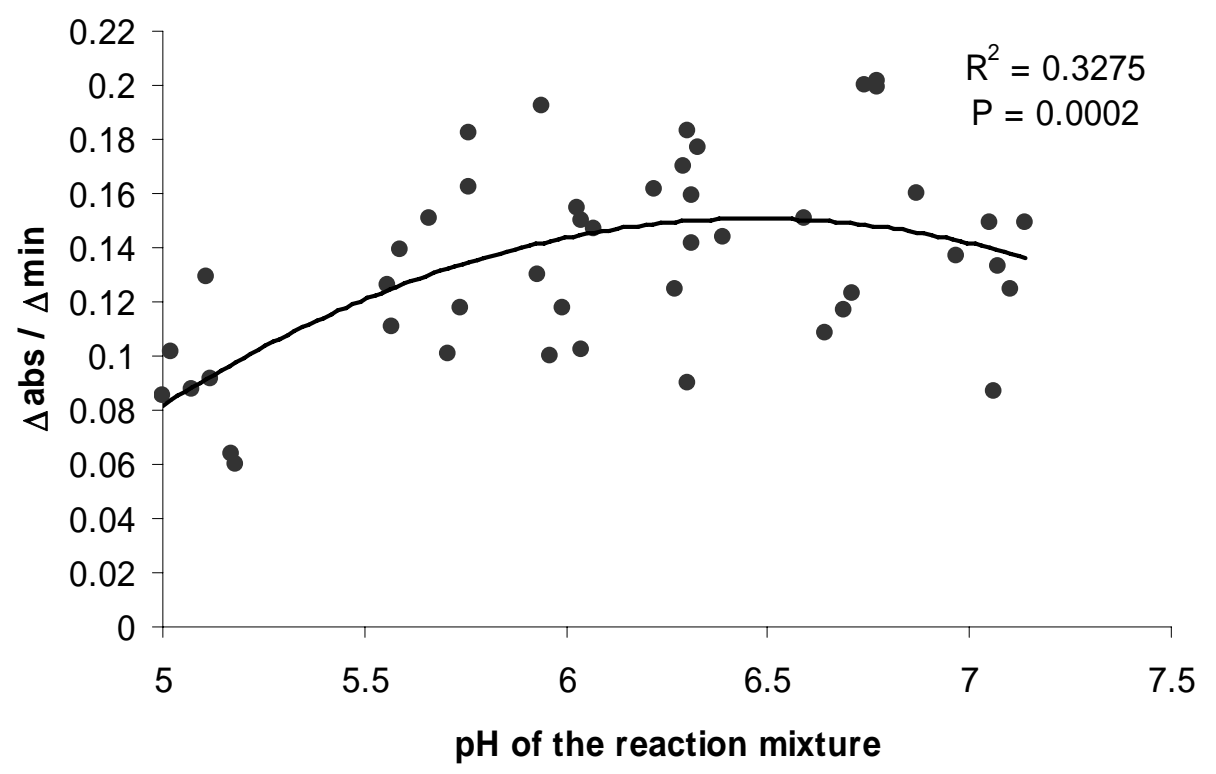

b)

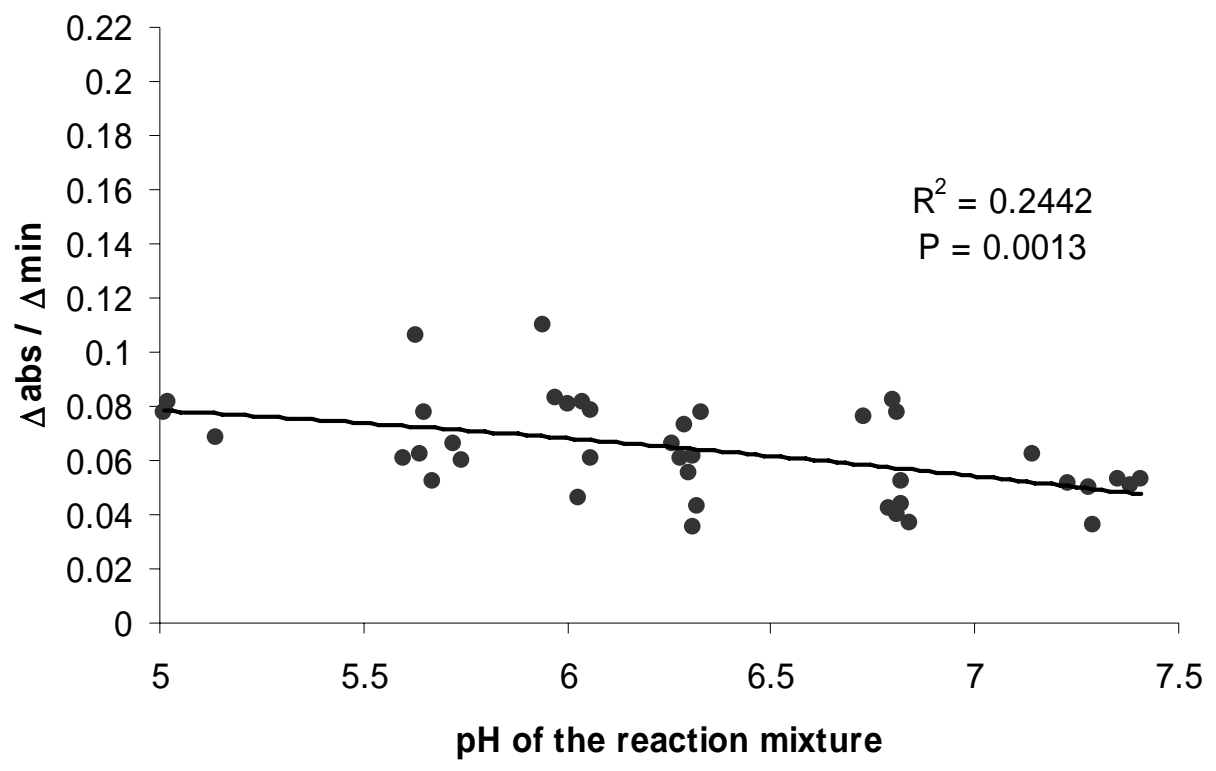


Fig. 2

a)

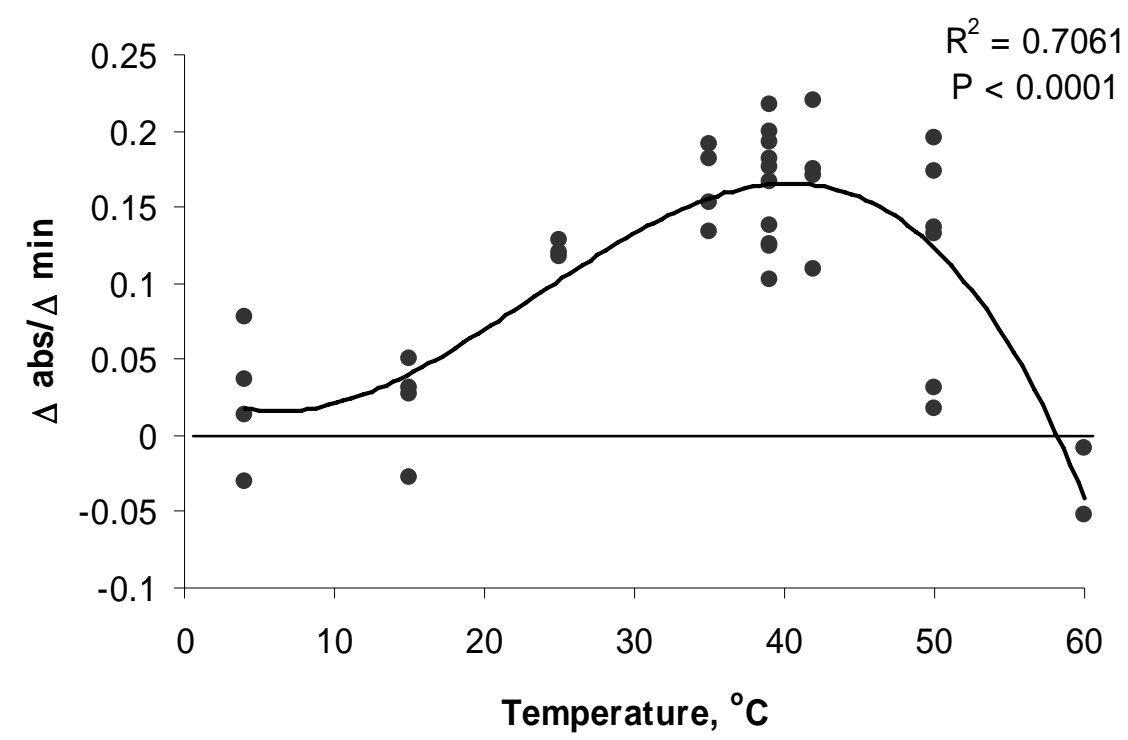

b)

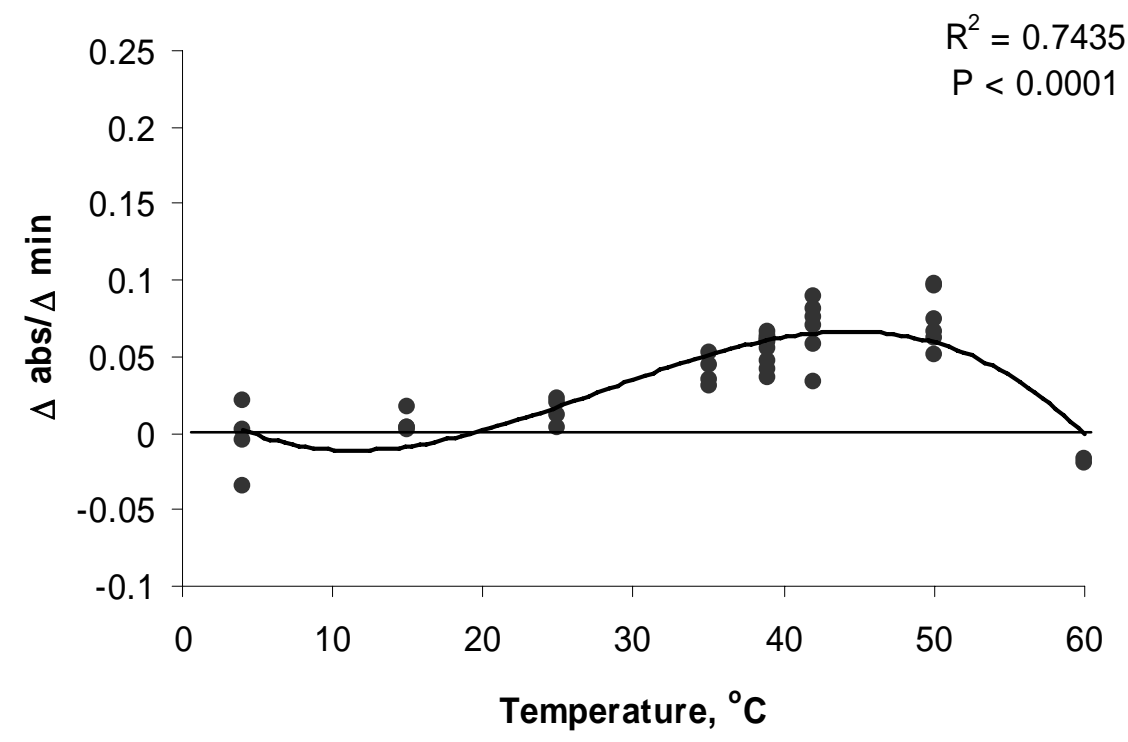

